This is an Accepted Manuscript of an article published by Taylor \& Francis in Journal of Interprofessional Care on 1 september 2017, available online: http://www.tandfonline.com/doi/

full/10.1080/13561820.2017.1346592 


\title{
New national curricula guidelines that support the use of interprofessional education in Brazilian context: an analysis of key documents
}

José Rodrigues Freire Filho, Marcelo Viana da Costa, Aldaísa Cassanho Forster, Scott Reeves Contact information: vianacostam@yahoo.com.br; vianacostam@icloud.com

\begin{abstract}
The National Curricular Guidelines (NCGs) are important documents for understanding the history of academic health professions education in Brazil. Key policies within the NCGs have helped to reorient health professions education and have stimulated curricular changes, including active learning methodologies, more integrated teaching-service environments and, more recently, have introduced interprofessional education (IPE) in both undergraduate and postgraduate sectors. This paper presents the findings of a study that examined the NCGs for nursing, dentistry and medicine courses as juridical foundations for adopting strategies that promote IPE across higher education institutions in Brazil. We employed a comparative and exploratory documentary analysis to understand the role of IPE or collaborative practices in NCGs for the three largest professions in Brazil. Following a thematic analysis of these texts, four key themes emerged: faculty development; competencies for teamwork; curricular structure; and learning metrics. Key findings related to each of these themes are presented and discussed in relation to the wider interprofessional literature. The paper goes on to argue that the statements contained in the NCGs about adoption of IPE and collaborative practices will have an important influence in shaping the future of health professions education in Brazil.
\end{abstract}

Key words: Interprofessional education; interprofessional learning, higher education; health professions; documentary analysis

\section{Introduction}

The global debate concerning health workforce issues includes as a central challenge to align education and training processes to initiatives that aim to strengthen health and social care systems (e.g. Crisp \& Chen, 2014). In this context, the complex and ever-evolving health and social needs pose demands for making effective change in systems of care. These demands point to the direction of fostering collaboration, enhancing teamwork and improving the quality of care delivered to patients (Frenk et al., 2010). 
In Brazil, the expansion of the National Unified Health System (known by the Portuguese acronym as SUS) is based on the values of universal and comprehensive care. These principles reinforce the need to invest in the reorientation of health services and health providers' training, justifying the need to strengthen the debate on interprofessional education (IPE) ${ }^{1}$ and collaborative work as key foundations. Similarly, several global recommendations point to the need to expand initiatives to consolidate IPE and collaborative practices as cornerstones of a new rationale for the delivery of effective healthcare (WHO, 2010; WHO, 2013).

Despite global developments that have gained momentum from two key publications which have argued for use of IPE (World Health Organization, 2010; Frenk et al., 2010), such studies are still scarce in Brazil. However, recent Brazilian experiences are beginning to make IPE a reality in both undergraduate and post-graduate sectors. Key policies re-orienting health professions education have stimulated curricular changes, including active learning methodologies, more integrated teaching environments as well as the expansion of IPE (Costa \& Borges, 2015; Costa, Patrício, Câmara, Azevedo \& Batista, 2015).

In the last 15 years, the main initiatives of this process have been: (1) the launch of the National Curricular Guidelines (NCGs) for health courses; (2) the National Program for Reorientation of Professional Training in Health (Pro-Saúde); and (3) the Program for Training Through Work in Health (PET-Saúde). All these initiatives are examples of successful practices designed to overcome the challenges of educating health professionals. Another milestone in this process has been the expansion of medical undergraduate courses to increase the supply of physicians, which has resulted in the adaption of other professional groups' curricular proposals to support these changes. Both aspects were included in the Federal Law 12871, approved on October 22 2013, assigning official status to the Mais Médicos (More Doctors) Program (Brasil, 2013).

The NCGs deserve a special mention as they represent the legal milestone of the reorientation process in health professions education and they also provide key guidance for the development of health education courses. In particular, they have provided important direction for changing the traditional model of didactic training towards a more active, student-centered approach. However, it is still unclear what role these NCGs may have for supporting IPE in Brazil.

\section{Background}

When exploring the nature of the NCGs, it is useful to understand the history of health professions 
education in Brazil to appreciate the current context within the country’s National Health System. Examining the NCG texts for medicine and nursing (published in 2001) and for dentistry (published in 2002) they provide a detailed series of expected profiles for future professionals as well as the competencies essential to strengthening the Brazilian health system (Ministério da Educação, 2001a; 2001b; 2002). Drawing upon these NCG documents, Streit, Barbosa Neto \& Lampert (2012) have helpfully highlighted key specific and generic competencies as well as course structures, methods of teaching and evaluation.

This development of competencies proposed by the NCGs aim to incorporate active learning methods which according to Puccini, Sampaio \& Batista (2008) will provide more autonomous learning and encourage a more in-depth understanding of health in the wider societal context. This process calls for academic, practitioner, citizen and community knowledge, thus inducing a deeper integration between health services and society.

For medicine, a major incentive for curricular revision was linked to the Federal Law 12871 that created Mais Médicos (Brasil, 2013). The Mais Médicos program aimed to improve the profession’s response to increasing population health demands while also strengthening SUS's health policies. A key area for this policy was the expansion of medical schools and curricular changes to ensure that future physicians would be educated in a way that would more appropriately meet the needs of SUS and the country. In some senses, the Mais Médicos triggered the NCGs revision process for medicine. Indeed, their legal contents provided additional support for a new approach to medical education and stimulated an updating of curricular objectives that were seen as outmoded (Ministério da Educação, 2001a).

In 2014, the new NCGs for medicine were officially enacted (Ministério da Educação, 2014) by decree of the National Council for Education (a body of the Ministry of Education). This document contained 41 articles that introduced new concepts as competencies, competency areas and competency domains, as well as proposals for strengthening teaching in primary, emergency and mental health care. In effect, these new NCGs reinforced the main components of Mais Médicos. While the 2014 guidelines were founded on the NCGs published in 2001 and 2002, they introduced new advancements in medical education, oriented by SUS doctrine, with the aim of more effectively meeting Brazilian population health needs.

This paper presents the findings of a study that aimed to explore and compare the NCGs for nursing, dentistry and medicine courses to understand their potential for promoting IPE in Brazil. While 
Brazil has 14 regulated health professions, the focus of this paper is on nursing, medicine and dentistry: the three largest professional groups in the country. These professions were also selected as they form the core groups of the national 'Family Health’ strategy in primary care.

\section{Methods}

Underpinned by social constructionism (Gergen, 2009), the study employed a comparative and exploratory documentary analysis to "describe and compare social behaviors, trends, differences and other features” (Figueiredo, 2007, p. 105) within the NCGs.

\section{Data collection}

The data gathered for this study (research corpus) were obtained from the 2001 NCGs for medicine and nursing, the 2002 NCGs for dentistry and the recently 2014 approved NCGs for medicine (Ministério da Educação, 2001a, 2001b, 2002, 2014). As noted above, these are important documents in informing professions education in Brazil. Specifically, the NCGs outline key features for curricular design as well as teaching/learning methodologies that are used in undergraduate health education across the entire country. Therefore, in-depth investigation of these NCGs would constitute a key step to understand the potential role of IPE in shaping the education of medicine, nursing and dentistry students.

\section{Data analysis}

The analysis of data was based on a thematic approach described by Bardin (2009, 2011). After downloading the official documents, an initial reading was made to become familiarized with these materials. During this phase, the NCG contents were examined to gather general impressions and to compose the corpus for the analysis. In the next phase, relevant text extracts from the NCGs were grouped together to form a series of themes. Finally, data in each of themes was summarized to allow a critical interpretation. A translation of these materials (from Portuguese to English) were subsequently undertaken before writing this paper.

\section{Results}

Analyzing the NCGs versions for nursing, dentistry and medicine undergraduate courses (Ministério da Educação, 2001a, 2001b, 2002, 2014), four themes (faculty development, competencies for teamwork, curricular structure, and learning metrics) emerged as key elements related to IPE. Each 
of these themes is presented in this section of the paper with supporting data from the NCGs.

\section{Faculty development}

In both the 2001 and 2002 NCGs (Ministério da Educação, 2001a; 2001b; 2002) there was no content related to supporting the development of educators' skills in relation to IPE facilitation. In contrast, the 2014 guidelines (Ministério da Educação, 2014) contained an explicit section mandating that medical education courses include IPE faculty development. Specifically, it was stated that faculty development should value teachers' work, involve different faculty members in course development activities and provide faculty training opportunities based on 'interdisciplinary,2 practices. As the following extract illustrates:

The undergraduate course of medicine must keep a permanent Teacher Training and Development in Health Program, aimed at the appreciation of teacher work in the undergraduate degree, the higher involvement of the teachers with the course's Pedagogic Project and its improvement in relation to the formative proposal contained in the document. This will be accomplished by means of the conceptual and pedagogic domains, encompassing active teaching strategies, based on interdisciplinary practices, so that they take on higher commitment with the transformation of the medical school, to be integrated to the daily life of teachers, students, staff and users of health services. (Ministério da Educação, 2014, Art. 34).

As noted above, a key element of this NCG was the adoption of faculty development opportunities aimed at supporting student learning of collaborative practice. Also, importantly, the document identified a need for faculty development activities to focus on how to integrate teachers, students, and users of the health services.

\section{Competencies for teamwork}

Both the 2001 and 2002 NCGs documents stated the need to create a range of competencies for health providers, covering health care delivery, decision-making, communication, leadership, management and lifelong learning. Although a number of the competencies had an implicit support for teamwork, only the communication and leadership competencies provided an explicit reference to (interprofessional) interaction:

Communication: health providers must be accessible and must keep confidentiality of the information provided to them when in interaction with other health providers and the public. (Ministério da Educação, Art. 4º, III, 2001a, 2001b; Art. 4º, III, 2002).

Leadership: in the multiprofessional teamwork, health providers must be apt to take over leadership positions, always having in mind the community’s welfare. Leadership comprises 
commitment, responsibility, empathy, skills for effective and efficient decision-making, communication and management. (Ministério da Educação, Art. 4º, IV, 2001a, 2001b; Art. $4^{0}$, IV, 2002).

While, as indicated above, the leadership competency statement supported the notion of medical leadership over other professional groups, the 2001 NCG for medicine did contain subsections which acknowledged the need for more (equitable) competencies in interprofessional communication, involvement of patients, family and community care and the adoption of teamwork:

III - communicating properly with co-workers, patients and their family members;

IV - informing and educating patients, family members and community in relation to health promotion, prevention, treatment and rehabilitation of diseases, using appropriate communication techniques;

XXI - acting in a multiprofessional team. (Ministério da Educação, 2001. art. 5)

Similarly, the 2001 NCG for nursing stated the need for interprofessional collaboration between nurses with the other health providers:

XXII - integrating nursing actions to the multiprofessional actions. (Ministério da Educação, 2002)

In relation to the NCG for dentistry, it was stated that there was a need for dentists to engage in teamwork with other health providers and ensure they communicated with patients and the wider communuty:

III - acting multiprofessionally and in an interdisciplinary and transdisciplinary way.

XXVII - communicating with patients, health providers and the community in general;

XXVIII - working in interdisciplinary teams and acting as a health promotion agent.

(Ministério da Educação, 2002. art. 5)

However, apart from these statements for the incorporation of teamwork, collaboration and communication, the 2001 and 2002 NCGs offered no details on these competencies.

In contrast, the 2014 NCGs listed 22 specific competencies which collectively provided stronger support for collaboration. For example, there was an explicit focus on working in a patient-centered manner as a member of an interprofessional team:

Person-centered, family and community-centered care, with an extensive interprofessional teamwork, developing horizontal, shared relations and respecting the needs and preferences of the person, the family and the community receiving care (...) and common responsibilities between health professionals and users. (Ministério da Educação, 2014, Art. 5). 
The 2014 document also provided a more detailed description of the competencies needed for the development of interprofessional collaborative practice. For instance, there was more information presented about collaboration in a number of sections, including 'health care', 'care management', and 'health education'. The document also explicitly referred to the need for integrating collaborative knowledge, skills and attitudes for the medical graduates to enable them to work effectively in an interprofessional manner, based on an interchange of knowledge with other health professionals:

Learning in an interprofessional way, based on the reflection on their own practice and the exchange of knowledge with health professionals and other areas of knowledge, to guide the identification and discussion of problems, stimulating the improvement of collaboration and health care quality. (Ministério da Educação, 2014, art.7).

Collaborative teamwork, respectful of the institutional norms in the work environments and acting under ethical and professional commitment to overcome the fragmentation of the work process in health. (Ministério da Educação, 2014, 2-14. art. 17).

In addition, the 2014 document stated the need for a clinical performance linked to a shared therapeutic process that involved an interprofessional approach. Collaborative work, joint participation and shared knowledge were all included as key competencies for medical graduates:

Use of different sources to identify problems in the work process, including the perspective of other professionals and users and the analysis of indicators and management model to identify risk and vulnerability of individuals, families and social groups. (Ministério da Educação, Art 17, I-c, p. 8).

Joint participation with users, social movements, health professionals, managers of health sector and others in the elaboration of intervention plans to face the prioritized problems. (Ministério da Educação, Art 17, II-a, p. 8)

\section{Curricular structure}

In relation to curricular structure issues, while the NCGs for nursing (2001), medicine (2001) and dentistry (2002) guidelines mentioned the need for improving collaboration, they offered only limited details. For example, article 12 of the 2001 NCG for medicine stated that curricular guidelines should have a focus on integration, interdisciplinarity and teamwork:

IV - promoting integration and interdisciplinarity coherent with the axis of curricular development, aiming to integrate the biological, psychological, social and environmental dimensions;

VI - using different teaching-learning settings, allowing the student to know and experience varied life situations, organization of the practice and work in multiprofessional team. 
(Ministério da Educação, 2001. art. 12)

However, as indicated in the above extract, there was a lack of information about the nature of integration and level of interprofessional interaction needed in the medical curriculum. Both the 2001 NCG for nursing and the 2002 NCG for dentistry contained similar statements on the structure of their respective curricula in regards to promoting interprofessional collaboration.

The 2014 NCG provided better conceptual clarity on interprofessionality. IPE was placed in a context of strengthening and consolidating the SUS, adding new perspectives in the educational process:

[The curriculum aims] to promote the integrality of the Pedagogic Project of the course using as a basis theory-practice articulation, integration with other knowledge fields and public institutions, SUS health services, training institutions and health care providers to foster a flexible and interprofessional education, connected to the main health problems of the population. (Ministério da Educação, 2014, Art. 29).

The 2014 guidelines also mandated the early integration of students in practice settings. In doing so, it recommended that students develop knowledge and experience of interprofessional team practice related to solving real life health problems. Specifically, the NCG required students to undertake interprofessional clinical experiences in primary and emergency care to integrate knowledge and practice. As the following excerpt highlights:

[Section I] encouragement of curiosity and the development of the ability to learn from everyone involved in the health work. (Ministério da Educação, Art. 20, 2014).

[Section II] identification of specific learning needs of people under their care and guardians, caregivers, family members, multidisciplinary teamwork, social groups or community, from a significant situation and respecting the previous knowledge and the cultural and social context of each one (Ministério da Educação, Art. 20, 2014).

\section{Learning metrics}

In general, the 2001 NCGs for medicine and nursing and the 2002 NCGs for dentistry presented few details related to learning metrics. Articles 13, 14 and 15 of these documents offered similar information about the need for the assessment of learning:

$\S 1$ The students' assessments should be based on the developed curricular competencies, skills and contents, having the curricular guidelines as a reference.

§2 The medicine undergraduate course should use methodologies and criteria for the follow up and assessment of the teaching learning process and the course itself, in consonance with the 
assessment system and the curricular dynamics established by the respective Higher Education Institution. (Ministério da Educação, 2001)

These documents did not however provide details about the type of assessment, when/how often to assess student learning, nor did they offer any explicit mention of the assessment of interprofessional curricular activities.

In contrast, the 2014 NCG provided more precise information. This document demanded that the assessment of both profession-specific and collaborative competencies was a mandatory requirement. It stated that assessment of competencies should be formative in nature and occur every two years until the end of a medical course:

The specific evaluation of Undergraduate Medical Course students shall be made every two years using tools and methodologies evaluating knowledge, skills and attitudes (...) mandatory, looking at the process, contextual and formative, and their results will be considered as part of the classificatory process for the tests conducive to Medical Residency programs. (Ministério da Educação, Art. 36, 2014).

\section{Discussion}

As presented above, the analysis of the NCGs for medicine, nursing and dentistry revealed that four themes connected to faculty development, competencies for teamwork, curricular structure, and learning metrics were key elements related to the development of IPE in Brazil. Below we discuss each of these themes in relation to the wider interprofessional literature.

When compared to the 2001 and 2002 NCGs, as important advance in the 2014 NCGs was the mandate to adopt interprofessional faculty development activities. This is a key element needed for the success of IPE. Indeed, a number of reports have stressed the need for faculty development to be provided to ensure that educators can effectively facilitate IPE to achieve core interprofessional competences (e.g. IPEC, 2011; Reeves et al., 2016). However, discussions about interprofessionality are in their early stages in Brazil. As a result, there is a need for an investment in processes that allow educators to understand IPE principles. Educators in health professions have traditionally taught using the same models (uni-professional) that they themselves were trained with - a process that can legitimate conventional practices and can hinder innovation and change (Becker, Geer, Hughes \& Strauss, 1961).

Providing faculty development that is focused supporting IPE can educators to develop and deliver 
active teaching/learning methods which can foster interprofessional interaction and a more collaborative culture (e.g. Schonwetter, Hamilton, \& Sawatzky, 2015; Sunguya, Hinthong, Jimba, \& Yasuoka, 2014). However, Lampert (2008) warned that medical educators may struggle in implementing the NCGs as "(teachers are) mainly trained in the previous, traditional, Flexnerian model still hegemonic in the healthcare environment [with] scarce time available to reflect on their own role and responsibility as teachers, as guides and facilitators of the teaching and learning process” (p. 34) - a situation which will limit their abilities to effectively engage in IPE facilitation. In addition, IPE faculty development activities can also be impeded by conflicting schedules, dispersion of facilities, varied curricular designs need to be integrated when planning IPE faculty development actions (Hall \& Zierler, 2015). In this sense, the inclusion of mandatory faculty development programs in the new NCGs (Ministério da Educação, 2014) should be a powerful tool to adopt IPE in the medical courses.

As indicated above, the 2014 NCGs introduced a debate of new interprofessional concepts that were not present in earlier guidelines (Ministério da Educação, 2001, 2002). A key concept was the prerequisite to educate health professionals that are more able to work collaboratively in teams. This shift towards interprofessionalism should encourage higher education institutions to give importance to interprofessional initiatives and to improve the qualifications of educators in line with the NCGs requirements for faculty development. Educators will clearly need this type of support - as recommended by the World Health Organization (2010) in their report on improving health professions education.

Regarding the competencies for teamwork, there were some remarkable aspects in the NCGs. While the 2001 and 2001 documents were explicit in stating a need for teamwork training, the 2014 NCG provided more refined and coherent terminology, and used concepts that supported IPE and collaborative practice principles. Indeed, one could see that this text presented a number of competencies which aligned well with the IPE literature. In particular, the ideas of Barr (1998) who introduced a series of IPE competencies which have been employed in later publications (CIHC, 2010; IPEC, 2011). As a result, the 2014 NCGs offer a coherent approach as they call for attention to interprofessional teamwork and collaboration as well as the need to ensure patients, families and the community is included in the center of team-based decision-making processes. Furthermore, these NCGs emphasized the need for the education process to be conducive to the generation of competencies for teamwork which support a patient, family and communities centered approach (e.g. Schonwetter et al., 2015). 
Related to the curricular structure, the 2001 and 2014 versions of the NCGs share some similarity, thus showing the continuity and relevance of the debate around teamwork in the Brazilian context. The 2001 guidelines noted incentives to adopt 'interdisciplinarity' and outlined the benefits of situating students in real life settings. The 2014 text went on to identify the need of building curricular structures that are linked with the macro dimensions of national health policies (Frenk et al., 2010). These documents also highlight the importance of interprofessional action as the most responsive and efficient way of addressing the health needs of the population (World Health Organization, 2010). Indeed, these NCGs identify the connection and coherence related to the use of IPE and the complex and dynamic needs of the health national and international landscape (Liu, Zhang, Liu, \& Wang, 2015).

The 2014 NCG recommendation regarding the use of active curricular methods offers a move forward for students to meet real-life challenges and problems. In particular, it puts students in the 'driving seat' of their learning supported by the teacher in the role of a facilitator (Melo \& Sant'Ana, 2012; Reeves, 2010). The emphasis in this NCG upon active curricular methods is a specific strength to adopt IPE, as these methodologies are part of a wider context integrated health courses (e.g. Towle \& Godolphin, 2013). The 2014 document also recognized the importance of IPE of encouraging medical students to share learning experiences with colleagues from other professional groups to understand the complexity of health problems (De Los Santos et al., 2014). In Brazil, the construction of the SUS demonstrates the importance of embedding key topics in health professions education (e.g. gender and ethnicity, SUS principles/guidelines/policies, comprehensiveness of care) that demand an interprofessional approach. The 2014 NCGs also recognize that both knowledge acquisition and the building values and attitudes according with social and health demands are needed (Kahaleh, Danielson, Franson, Nuffer, \& Umland, 2015).

In regards to learning metrics, as presented above, the NCGs recommended that a formative (process) approach to assessment is needed. Learners should be informed about their progress and given feedback related to any difficulties encountered on a regular basis, allowing opportunities for improvement (Caseiro \& Gebran, 2010). This approach can also stimulate active dialogue and action among between educators and learners. The 2014 NCGs can be seen as a step forward in the way of establishing a stable process of assessment, which is synergic with other pillars for change, such as faculty development, user-centered active methodologies and incentives for shared decision-making. The 2014 NCG also advocated for the assessment of competencies developed during the training process, including profession-specific and collaborative competencies. However, developing IPE 
across the national context will demand additional efforts from all stakeholders. Debating the inclusion of interprofessionality in medical education will inevitably involve a need to revisit the traditional assessment processes to add new ways of measuring values, attitudes, knowledge and skills that support the effective teamwork rationale centered on patients' needs (e.g. Simmons \& Wagner, 2009).

The analysis of the NCGs documents (Ministério da Educação, 2001, 2002 and 2014) can be usefully framed by Oandasan \& Reeves' (2005) three dimensions (macro, meso, micro) related to the implementation of IPE. At the macro-level, transformations in the policies that guide the teaching institutions need to occur; at the meso-level, curricular, program, methodological and pedagogic changes need to occur; and at the micro-level, there is a need to change interpersonal and interprofessional relationships. Recognizing the relevance of macro, meso and micro activities for the successful implementation of IPE, it can be argued that the 2014 guidelines should play an important role in the macro-level because they can encourage major changes in curriculum structures and interpersonal and interprofessional relationships in training health professionals. As a legally valid framework, the 2014 NCGs are part of the macro dimension and bring relevance to important dimensions that influence both the meso and the micro level in the curricular design, in contents adoption, as well as in interpersonal and interprofessional interactions.

Despite some significant advances, the 2014 NCGs still need to overcome the conceptual confusion linked to the interchangeable use the terms such as "interdisciplinary" and "interprofessional". In Brazil, there are important theoretical contributions on teamwork, using the terms "interdisciplinary" or “multiprofessional” (Peduzzi, Palma \& Mendes-Gonçalves, 2000; Peduzzi, 2001; Ceccim, 2004). However, in recent years the national literature is reinforcing the need for further discussion and clarification on the theoretical and methodological basis of IPE (Peduzzi, Norman, Germani, Silva \& Souza, 2013; Agreli, Peduzzi, Loqueti \& Silva, 2014; Costa et al, 2015). This view is supported in the international literature which has emphasized the importance of overcoming conceptual confusion in order to ensure more robust implementation and evaluation of IPE (Goldman, Zwarenstein, Bhattacharyya, \& Reeves, 2009; Reeves, Lewin, Espin, \& Zwarenstein, 2010).

In relation to the study limitations, we only analyzed three documents (NCGs for undergraduate courses in nursing, medicine and dentistry). Also, possible researcher bias may have also been introduced in the analysis of these documents. Future research is needed to examine the adoption of IPE in guidelines for other undergraduate health courses. Research is also needed to describe any changes resulting from the implementation of the NCGs across the different regions of Brazil. In 
addition, further research is needed to describe the efforts of medical schools in adopting the new guidelines, showcasing the experiences of integrating IPE in their respective curricula.

\section{Concluding comments}

As presented above, the NCGs have highlighted the need for interprofessional competencies to shape the future of health professions education in Brazil. The emphasis that these guidelines have given to interprofessionality in education and practice in Brazil supports a growth of these activities around the world. Despite some conceptual confusion still present in the text of the 2014 NCGs, interprofessionality is regarded as a central foundation for reforming education and practice in Brazil. The move towards IPE is also complementary in supporting other reforms in the country, such as the integration between universities, health services and the community.

The 2014 NCGs specifically provide motivation for medical educators to shift toward embracing shared learning processes, drawing upon interprofessional communication processes and collaborative patient-centered initiatives. The guidelines encourage medical schools to reflect on the delivery of their education content, to advance it in several critical aspects towards producing graduates whose abilities are a better fit to meet the needs of the Brazilian health system.

Many challenges however lie ahead with the implementation of IPE across Brazil. However, undertaking and dissemination research related to the implementation the new guidelines will provide important evidence about this process. It should also help create a collaborative network oriented towards the strengthening the national health system to become more resilient and better aligned with the health and social needs of the Brazilian population.

\section{Notes}

1. In this paper, we use the definition of IPE developed by the Centre for the Advancement of Interprofessional Education (CAIPE), who defined IPE as an activity which occurs when two or more health professions learn about, from and with each other to enable effective collaboration and delivery of patient/client care (CAIPE, 2002).

2. The NCGs documents use the terms 'interdisciplinary', 'interprofessional' and 'multiprofessional' interchangeably without acknowledging the conceptual differences related to these terms.

\section{Declaration of interest}


The authors report no conflicts of interest. The authors alone are responsible for the writing and content of this article.

\section{References}

Bardin, L. (2009). Análise de Conteúdo. Lisboa-Portugal: Edições 70.

Bardin, L. (2011). Análise de Conteúdo. Lisboa: Edições 70.

Barr, H. (1998). Competent to collaborate: Towards a competency-based model for interprofessional education. Journal of Interprofessional Care, 12(2), 181-187. doi:10.3109/13561829809014104

Becker, H.S; Geer, B; Hughes, E.C; Strauss, A.L. (1961). Boys in white: student culture in medical school. Chicago: The University of Chigado Press.

Brasil. (2013). Lei $n^{0}$ 12.871, de 22 de outubro de 2013. Institui o Programa Mais Médicos, altera as Leis n. 8.745, de 9 de dezembro de 1993, e n. 6.932, de 7 de julho de 1981, e dá outras providências. Diário Oficial da União.

CAIPE [Centre for the Advancement of Interprofessional Education] (2002). Centre for the Advancement of Interprofessional Education.

CIHC [Canadian Interprofessional Health Collaborative] (2010). A National Interprofessional Competency Framework. Vancouver, BC: College of Health Disciplines University of British Columbia.

Caseiro, C. C. F., \& Gebran, R. A. (2010). Avaliação formativa: concepção, práticas e dificuldades. Nuances: estudos sobre Educação, 15(16).

Costa, M. V. d., \& Borges, F. A. (2015). O Pró-PET-Saúde frente aos desafios do processo de formação profissional em saúde. Interface - Comunicação, Saúde, Educação, 19, 753-763.

Costa, M. V. d., Patrício, K. P., Câmara, A. M. C. S., Azevedo, G. D., \& Batista, S. H. S. d. S. (2015). Pró-Saúde e PET-Saúde como espaços de educação interprofissional. Interface Comunicação, Saúde, Educação, 19, 709-720.

Crisp, N., \& Chen, L. (2014). Global Supply of Health Professionals. New England Journal of Medicine, 370(10), 950-957.

Ceccim, R. B. (2004). Equipe de saúde: a perspectiva entre-disciplinar na produção dos atos terapêuticos. Cuidado: as fronteiras da integralidade, 3, 259-78.

De Los Santos, M., McFarlin, C. D., \& Martin, L. (2014). Interprofessional education and service learning: a model for the future of health professions education. Journal of Interprofessional Care, 28(4), 374-375. doi:10.3109/13561820.2014.889102

Figueiredo, N. M. A. d. (2007). Método e metodologia na pesquisa científica (2 ed ed.). São Caetano do Sul - SP: Yendis Editora. 
Frenk, J., Chen, L., Bhutta, Z. A., Cohen, J., Crisp, N., Evans, T., . . Zurayk, H. (2010). Health professionals for a new century: transforming education to strengthen health systems in an interdependent world. Lancet, 376(9756), 1923-1958. doi:10.1016/S0140- 6736(10)61854-5

Gergen, K. J. (2009). Realities and relationships: Soundings in social construction. Harvard university press.

Goldman, J., Zwarenstein, M., Bhattacharyya, O., \& Reeves, S. (2009). Improving the clarity of the interprofessional field: Implications for research and continuing interprofessional education. Journal of Continuing Education in the Health Professions, 29(3), 151-156. doi:10.1002/chp.20028

Hall, L. W., \& Zierler, B. K. (2015). Interprofessional Education and Practice Guide No. 1: developing faculty to effectively facilitate interprofessional education. $J$ Interprof Care, 29(1), 3-7. doi:10.3109/13561820.2014.937483

IPEC [Interprofessional Education Collaborative Expert Panel] (2011) Core competencies for interprofessional collaborative practice: Report of an expert panel. Washington, DC: Interprofessional Education Collaborative.

Kahaleh, A. A., Danielson, J., Franson, K. L., Nuffer, W. A., \& Umland, E. M. (2015). An Interprofessional Education Panel on Development, Implementation, and Assessment Strategies. Am J Pharm Educ, 79(6), 78. doi:10.5688/ajpe79678

Lampert, J. B. (2008). Dois séculos de escolas médicas no Brasil e a avaliação do ensino médico no Panorama atual e perspectivas. Gazeta Médica da Bahia, 78(1).

Liu, Y., Zhang, Y., Liu, Z., \& Wang, J. (2015). Gaps in studies of global health education: an empirical literature review. Global Health Action, 8, 10.3402/gha.v3408.25709. doi:10.3402/gha.v8.25709

Melo, B. d. C., \& Sant'Ana, G. (2012). A prática da Metodologia Ativa: compreensão dosdiscentes enquanto autores do processo ensinoaprendizagem. Comun. ciênc. saúde, 23(4), 327-339.

Ministério da Educação (2001a). Conselho Nacional de Educação. Câmara de Educação Superior. Resolução CNE/CES no 3, de 7 de novembro de 2001: Institui Diretrizes Curriculares Nacionais do Curso de Graduação em Enfermagem. Diario Oficial Uniao. 09 nov 2001[citado 2008 set 22];Seção1:37. Disponível em: http://portal.mec.gov.br/cne/arquivos/pdf/CES03.pdf

Ministério da Educação. (2001b). Conselho Nacional de Educação. Câmara de Educação Superior. Resolução CNE/CES no 4, de 7 de novembro de 2001: Institui Diretrizes Curriculares Nacionais do Curso de Graduação em Medicina. Diario Oficial União. 09 nov 2001[citado 2008 set 22];Seção1:38. Disponível em:

http://portal.mec.gov.br/cne/arquivos/pdf/CES04.pdf.

Ministério da Educação. (2002). Conselho Nacional de Educação Câmara de Educação Superior. Resolução CNE/CES 3, de 19 de fevereiro de 2002. Institui Diretrizes Curriculares Nacionais do Curso de Graduação em Odontologia. Diario Oficial Uniao. 04 mar 2002[citado 2008 set 22];Seção1:10. Disponível em: http://portal.mec.gov.br/cne/arquivos/pdf/ CES032002.pdf 
Ministério da Educação. (2014). Resolução CNE/CES n ${ }^{\circ}$ 3, de 20 de junho de 2014. Institui as Diretrizes Curriculares Nacionais dos Cursos de Graduação em Medicina e dá outras providências. Brasília-DF: Diário Oficial da União.

Oandasan, I., \& Reeves, S. (2005). Key elements for interprofessional education. Part 1: The learner, the educator and the learning context. Journal of Interprofessional Care, 19, 21-38. doi:10.1080/13561820500083550

Interprofessional Education Collaborative (2011). Core competencies for interprofessional collaborative practice: Report of an expert panel: Interprofessional Education Collaborative Expert Panel.

Peduzzi, M., Palma, J. J. L., \& Mendes-Gonçalves, R. B. (2000). A equipe de saúde. In Saúde em Debate, 96: Série Didática, Vol. 3, pp. 234-250. Hucitec.

Peduzzi, Marina. (2001). Equipe multiprofissional de saúde: conceito e tipologia. Revista de Saúde Pública, 35(1), 103-109. https://dx.doi.org/10.1590/S0034-89102001000100016.

Peduzzi, M., Norman, I., Germani, A., Silva, J., \& Souza, G. (2013). Educacao interprofissional: formação de profissionais de saúde para o trabalho em equipe com foco nos usuarios. Revista da Escola de Enfermagem da USP, 47(4), 977-983. doi:http://dx.doi.org/10.1590/reeusp.v47i4.78051

Agreli, H. L. F., Peduzzi, M., Loqueti, C., \& Silva, M. C. (2014). Atenção Centrada no Usuário como Atributo do Trabalho em Equipe e Prática Interprofissional Colaborativa na Atenção Básica. Blucher Medical Proceedings, 1(2), 263-263.

Puccini, R. F., Sampaio, L. d. O., \& Batista, N. A. (2008). A formação médica na Unifesp: excelência e compromisso social: Editora Fap-Unifesp.

Reeves, S. (2010). The need to problematize interprofessional education and practice activities. Journal of Interprofessional Care, 24(4), 333-335. doi:10.3109/13561820.2010.492748

Reeves, S., Lewin, S., Espin, S., \& Zwarenstein, M. (2010). Interprofessional teamwork for health and social care. Chichester: Wiley-Blackwell.

Reeves S, Pelone F, Hendry J, Lock N, Marshall J, Pillay L, Wood R (2016) Using a metaethnographic approach to explore the nature of facilitation and teaching approaches employed in interprofessional education. Medical Teacher; 38:1221-1228

Schonwetter, D. J., Hamilton, J., \& Sawatzky, J. A. (2015). Exploring professional development needs of educators in the health sciences professions. Journal of Dental Education, 79(2), 113-123.

Simmons, B., \& Wagner, S. (2009). Assessment of continuing interprofessional education: Lessons learned. Journal of Continuing Education in the Health Professions, 29(3), 168-171. doi:10.1002/chp.20031

Stella, R. C. d. R., \& Campos, J. J. B. d. (2006). Histórico da construção das Diretrizes Curriculares Nacionais na graduação em medicina no Brasil. Cad Abem, 2, 77. 
Streit, D. S., Barbosa Neto, F., \& Lampert, J. (2012). 100 Anos de Diretrizes Curriculares Nacionais. Cadernos de Educação Médica. Retrieved from

Sunguya, B. F., Hinthong, W., Jimba, M., \& Yasuoka, J. (2014). Interprofessional education for whom? --challenges and lessons learned from its implementation in developed countries and their application to developing countries: a systematic review. PLoS One, 9(5), e96724. doi:10.1371/journal.pone.0096724

Towle, A., \& Godolphin, W. (2013). Patients as educators: Interprofessional learning for patientcentred care. Medical Teacher, 35(3), 219-225. doi:10.3109/0142159x.2012.737966

World Health Organization (WHO). (2010). Framework for action on interprofessional education \& collaborative practice. Geneva: World Health Organization.

World Health Organization (WHO). (2013). WHO education guidelines: Transforming and scaling up heath professionals' education and training. Geneva: World Health Organization. 